\title{
KOULUTUS ON KANNATTAVA INVESTOINTI NIIN YKSILÖILLE KUIN ALUETALOUDELLEKIN
}

\author{
"Koulutuksen ja talouden välisiä suhteita käsittelevä aihepiiri ei ole uusi \\ tutkimusalue. Uutta on sen sijaan painotus”, kirjoittaa Toni Saarivirta \\ lektiossaan. Hän väitteli toukokuun lopussa Tampereella tutkimuksellaan \\ koulutuksen ja tutkimuksen taloudellisesta merkityksestä. Siinä hän tutki \\ yliopistollisen koulutuksen ja tutkimuksen merkitystä seitsemällä alueella.
}

$\mathrm{U}$ seat koulutuksen taloudellista merkitys tä tarkastelleet tutkijat ovat sijoittaneet aihepiirin alkuvaiheet skotlantilaiseen taloustieteilijään, filosofiin Adam Smithiin ja hänen jo vuonna 1776 julkaistuun teokseen "Kansakuntien varallisuus”. Smithin mukaan työntekijän taitojen lisäämiseksi käytetty summa maksaa itsensä takaisin, koska taitavampi työntekijä on tuottavampi. (esim. Psacharopoulos 2000.)

Missä henkilön tiedot ja taidot sitten lisääntyvät? Yksi keskeisimmistä paikoista on luonnollisesti koulu, vaikka oppimista tietenkin tapahtuu muuallakin. Vuorovaikutusketju: koulu @ lisääntyneet tiedot ja taidot $₫$ korkeampi tuottavuus, ei ole kuitenkaan lineaarinen, vaikka alan kirjallisuus sen helposti näkeekin niin. Taloustieteilijät ovat tunnettuja siitä, että he asettavat mielellään oletuksia. Oletukset eivät toimi täydellisesti reaalimaailmassa, mutta niitä tarvitaan, jotta ilmiöitä voitaisiin tarkastella. Tämä pätee useampaan tieteenalaan. Teoreettinen malli on aina yksinkertaistettu kuvaus todellisuudesta. Mallit luonnollisesti muuttuvat ja kehittyvät ajan kuluessa.

Miksi sitten koulutusta, tutkimusta ja taloudellista kehitystä on mielekästä tarkastella samassa viitekehyksessä? Asioiden yhteennivoutuminen ei etene kronologisessa järjestyksessä. Taloudelliseen kehitykseen ja kasvuun liittyvät teoriat ovat lähes yhtä vanhoja kuin itse taloustiedekin. Varsinaisen alkusysäyksen kasvuteorioiden kehittelylle antoi kuitenkin vuoden 1929 Wall Stree- tin pörssiromahdus ja sen jälkeinen aika. Lama levisi ympäri maailman.

Yksi eniten käytetyistä kasvuteorioista on ns. Solowin neoklassinen kasvuteoria. Teoria poikkeaa aikaisemmista teorioista siinä, että se ottaa huomioon myös teknologisen kehityksen. Teorian muut muuttujat ovat työvoima ja fyysinen pääoma. Teknologinen kehitys on Solowin teoriassa ns. eksogeeninen tekijä, eli eräänlaista mannaa taivaasta, joka vaan ilmaan-

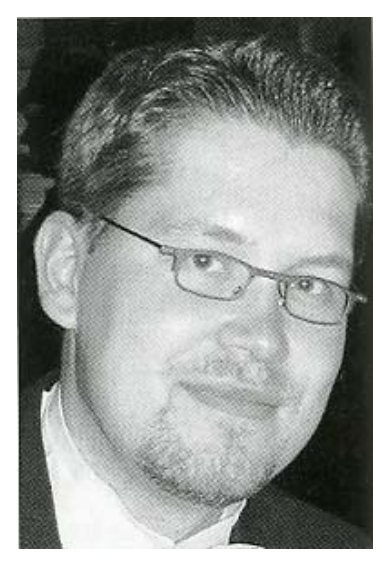

Toni Saarivirta tuu jostain ja sitä aletaan käyttää. (Solow 1956, Fagerberg 1994, Mulder \& De Groot \& Hofkes 2001, Screpanti \& Zamagani 1993, England 2000.)

Solowin 1950-luvulla kehittämä malli ei kuitenkaan ole pystynyt täysin selittämään taloudellista kasvua. Selittämättä jäänyttä, usein noin kolmasosaa, kutsutaan Solowin residuaaliksi. Jäljelle jäänyt residuaali on eräänlainen musta-aukko, jota paikkaamaan on käytetty tietoja, taitoja, koulutusta ja tutkimusta.

\section{INHIMILLISEN PÄÄOMAN TEORIAN PÄTEVÄ?}

Koulutuksen taloudellisen merkityksen tutkiminen yksilötasolla juontaa juurensa 1950-60-luvuil- 
le, jolloin taloustieteilijät alkoivat kehitellä teoriaa, joka tunnetaan nimellä inhimillisen pääoman teoria. (esim. Blaug 1976, Woodhall 1987, Vaherva \& Juva 1985.) Teorian keskeinen kysymys on, miksi enemmän koulutusta omaavat ihmiset ympäri maailmaa ansaitsevat keskimäärin enemmän kuin vähemmän koulutetut? Ekonomistit näkevät asian liittyvän työn tuottavuuteen. Mitä enemmän koulutusta, sitä tuottavampi henkilö. Tässä yksinkertaistetusti syy keskimääräisiin palkkaeroihin. Teorian mukaan enemmän koulutusta omaavien henkilöiden onkin ansaittava enemmän, koska he ovat investoineet koulutukseensa enemmän kuin vähemmän koulutusta omaavat henkilöt. Tilastojen valossa tehdyt tutkimukset tarkastelevat ilmiötä ns. aggregaattitasolla, jolloin puhutaan esimerkiksi pelkästään perusasteen koulutuksesta, toisen asteen koulutuksesta ja korkeakoulutuksesta. Varsinkin korkeakoulutuksen osalta löytyy tieteenaloja, joiden opiskelijat eivät saa koskaan koulutuksestaan tuottoa, ts. investoinnista saatu rahallinen hyöty jää investointikustannuksia alhaisemmaksi. Perusasteen koulutus on yksittäisen henkilön kannalta paras investointi: muutaman vuoden koulutus nostaa ansiotuloja niin, että koulutuksen tuottoaste on keskimäärin muita asteita parempi (esimerkiksi Psacharopoulos \& Patrinos 2002). Inhimillisen pääoman teoria on saanut osakseen luonnollisesti kritiikkiäkin, mutta en mene tuohon kritiikkiin sen tarkemmin.

\section{"UUSI KASVUTEORIA"}

Solowin mallin heikkoudet ovat tulleet entistä selvemmin esiin maailmantalouden avautuessa. Kaikkien maiden pitäisi periaatteessa olla samassa asemassa, jos teknologian muutokset ovat satunnaisia ja "mannaa taivaasta”. Rikkaiden ja köyhien maiden välillä on toki tapahtunut lähentymistä, mutta se on ollut hidasta. Koulutuksen lisääminen kasvuteoreettiseen malliin on 1980luvun lopun tuotetta. Teoriasta käytetään nimeä uusi kasvuteoria. Huomattiin, että kun työntekijöiden tietoja ja taitoja mallinnetaan koulutuksen (ts. koulutusvuosien kautta), mallien selitysasteet paranevat merkittävästi. Asian ydin piilee teknologisen kehityksen taustalla olevissa tekijöissä. Teknologinen kehitys ei siis ole "mannaa taivaasta”, vaan sen takana ovat innovaatiot, koulutus ja tutkimus. Inhimillisen pääoman lisääntyminen edesauttaa uusien ideoiden syntyä, joita edelleen hyödyntämällä saadaan aikaan taloudellista kasvua. Uuden kasvuteorian mukaan tuotekehitystoimintaa on edistettävä, koulutukseen ja oppimiseen panostettava ja teknologian tasoa on kohotettava. Uusi kasvuteoria korostaa ideoiden ja niihin pohjautuvien aineettomien hyödykkeiden poikkeavuutta perinteisistä konkreettisista tuotteista. Teorian mukaan tieto on vapaasti käytettävissä, eikä se ole muilta poissuljettu. (Romer 1986, Romer 1989, Barro \& Sala-I- Martin 1995, Romer 1990, Juniper 2002.)

Olen tarkastellut työssäni koulutuksen ja tutkimuksen aluetaloudellista merkitystä. Painopiste on ollut erityisesti yliopistollisen toiminnan taloudellisen merkityksen tarkastelussa. Tutkimukseni empiirisenä kohteena ovat olleet 1960luvun jälkeiset yliopistopaikkakunnat ja Satakunta.

Kirjallisuuden ja aikaisempien tutkimusten mukaan (esim. Luger \& Goldstein 1997, Keane \& Allison 1999, Sudmant 1999, Clinch \& Gerlowski 2002, Macfarland 2001, Duhart 2002) yliopistojen aluetaloudellinen merkitys voidaan pääsääntöisesti kiteyttää seuraavaan kolmeen kohtaan: 1) yliopistoilla on suora kulutusvaikutus alueilleen, 2) yliopistot kouluttavat työvoimaa ja 3) yliopistot toimivat tietoon perustuvan talouden yhtenä tärkeimmistä lähteistä. Tämän lisäksi voitaisiin vielä mainita imagotekijä: yliopistoilla on positiivinen imago ja ne luovat alueilleen vetovoimaisuutta.

Pyrin vastaamaan tutkimuksessani seuraaviin kysymyksiin:

1) Millainen merkitys yliopistollisella toiminnalla on aluetaloudelle ja voiko sitä eksplisiittisesti määrittää? Onko koulutuksen ja taloudellisen kehityksen välillä positiivinen korrelaatio? Onko eri koulutustasoilla erilainen merkitys alueen taloudellisessa kehityksessä?

2) Mistä yliopistot rekrytoivat opiskelijansa ja minne opiskelijat valmistumisensa jälkeen sijoittuvat?

3) Kuinka innovatiivisia tutkittavat alueet ovat ja onko innovatiivisuudella ja taloudellisella kehityksellä yhteys?

Tutkimukseni empiirinen aineisto muodostuu tilastollisesta materiaalista, jonka hankin tilastokeskuksen Altika-tietokannasta, tilastokeskuksen julkaisusarjoista, opetusministeriön Kota-tietokannasta, patentti- ja rekisterihallitukselta, Joensuun yliopiston ATK-keskuksesta, Tampereen yliopiston yhteiskuntatieteellisestä tietoarkistos- 
ta ja yliopistojen vuosikirjoista ja toimintakertomuksista.

\section{TUTKIMUKSEN KESKEISET TULOKSET}

Nostan seuraavassa esille keskeiset tutkimustulokseni.

Yliopistollisella toiminnalla on positiivinen merkitys aluetaloudelle ja se voidaan tiettyyn pisteeseen saakka eksplisiittisesti määrittää. Yliopistot itsenään ovat alueillaan taloudellisia toimijoita, jotka investoivat ja luovat kulutuskysyntää, tuovat alueelle opiskelijoita ja tuottavat työvoimaa. Panos-tuotosanalyysin pohjalta yliopistojen taloudellinen vaikutus voidaan karkeasti arvioida ja sen perusteella esittää euromääräisiä lukuja. Lisäksi yliopistojen osuus alueiden tutkimus- ja tuotekehitysrahoituksesta on valtava: esimerkiksi Pohjois-Savossa ja Etelä-Karjalassa yli puolet kaikista maakuntien tutkimus- ja tuotekehitysmenoista ovat yliopistosidonnaisia. Yliopistojen välillistä merkitystä ei sen sijaan pysty eksplisiittisesti määrittämään ja siitä voi vain esittää arvioita.

Koulutuksen ja taloudellisen kehityksen välillä vallitsee vahva positiivinen korrelaatio ja eri koulutustasoilla on erilainen aluetaloudellinen merkitys. Ei kuitenkaan voida sanoa, että mitä enemmän koulutusta koulutusvuosilla mitattuna alueilla on, sitä parempi on alueiden taloudellinen kehitys. Tämä johtuu alueiden elinkeinorakenteista ja siitä, että ihmiset työskentelevät erilaisissa tehtävissä. Tuotantofunktion analyysin perustuen korkeakoulutuksella on joka tapauksessa aluetalouteen positiivinen merkitys kaikilla tutkituilla alueilla Porin ja Vaasan seutukuntia ja Satakuntaa lukuun ottamatta. Näillä alueilla vastaavasti keskiasteen koulutuksella on aluetalouteen positiivinen merkitys. Tiivistetysti voi sanoa, että koulutus itsessään ei ole ratkaisu taloudellisen kehityksen edistämiseen, vaan se on tiiviisti yhteydessä ympäröivään yhteiskuntaan.

Suurin osa yliopistojen opiskelijoista rekrytoituu opiskelijaksi lähialueelta. Jos opiskelijan syntymäalue on sama kuin yliopiston sijaintialue, opiskelija myös sitä todennäköisemmin jää valmistuttuaan alueelle. Muualta muuttaneet opiskelijat sen sijaan jatkavat valmistuttuaan matkaansa erityisesti Uudellemaalle. Eniten muualta kuin yliopiston sijaintialueelta muuttaneita opiskelijoita jää erityisesti Kuopion, Lapin ja Turun alueille.
MITÄ PATENTTIHAKEMUSTEN MÄÄRÄT KERTOVAT?

Innovatiivisuus ja taloudellinen kehitys näyttävät tutkimukseni tulosten perusteella kulkevan käsi kädessä seutukuntatasolla, mutta ei maakuntatasolla. Innovatiivisuutta tarkastelin alueilta lähetettyjen patenttihakemusten valossa. Korkein arvonlisäys/työntekijää kohden on Rauman seutukunnassa, josta myös on lähetetty eniten patenttihakemuksia. Alhaisin arvonlisäys/työntekijä on vastaavasti Rovaniemen seutukunnassa ja sieltä on myös lähetetty vähiten patenttihakemuksia. Tämän johdosta voisikin päätellä, että keskeisten seutukuntien innovatiivisuus ei riitä kantamaan koko maakunnan tasolle eikä siten edistämään maakuntien taloudellista kehitystä.

Tutkimustulosten perusteella voidaan kuitenkin sanoa, että koulutus on kannattava investointi paitsi yksityiselle henkilölle, myös aluetaloudelle. Vaikka muutamalla alueella korkeakoulutuksella ei näyttänyt olevan merkitystä alueiden arvonlisäykseen, se ei silti tarkoita, että alueiden korkeakoulutetuilla ei olisi mitään merkitystä aluetaloudelle. Monet korkeakoulutettujen taloudelliset vaikutukset ovat välillisiä, eikä niitä pysty tarkastelemaan määrällisin mittarein.

\section{LÄHTEET}

Barro, R. J. \& Sala-I-Martin, X. (1995). Economic Growth. McGraw-Hill Advanced Series in Economics. USA.

Blaug, M. (1976). An Introduction to the Economics of Education. Penguin Books. Cox \& Wyman Ltd. London (first published by Allen Lane The Penguin Press 1970).

Clinch, R. P. \& Gerlowski, D. A. (2002). The Economic Impact of the University System of Maryland: A Fiscal Perspective. Adelphi, Maryland.

Duhart, S. R. (2002). The Economic Impact of University System of Georgia Institutions on Their Regional Economics. A Needs' Assessment Study. Georgia.

England, R. W. (2000). Analysis. Natural capital and the theory of economic growth. Ecological Economics, 34, pp. 425-431.

Fagerberg, J. (1994). Technology and International Differences in Growth Rates. Journal of Economic Literature. Vol. XXXII, pp. 1147-1175. 
Juniper, J. (2002). Universities and Collaboration within Complex, Uncertain KnowledgeBased Economies. Critical Perspectives on Accounting 13, pp. 747-778.

Keane, J. \& Allison, J. (1999). The Intersection of the Learning Region and Local and Regional Economic Development: Analysing the Role of Higher Education. Regional Studies, pp. 896-902.

Luger, M. I. \& Goldstein, H. A. (1997). What is the Role of Public Universities in Regional Economic Development? Teoksessa Bingham, R. D. \& Mier, R. (Eds.): Dilemmas of Urban Economic Development. Issues in Theory and Practise. Urban Affairs Annual Reviews 47. SAGE Publications. California.

MacFarland, T. W. (2001). An Estimate of Nova Southeastern University's Economic Impact on South Florida and Florida for Fiscal Year 2000. Nova Souhteastern University Research and Planning.

Mulder, P. \& De Groot, H. L. F. \& Hofkes, M. W. (2001). Economic growth and technological change: A comparison of insights from a neo-classical and an evolutionary perspective. Technological Forecasting \& Social Change, 68, pp. 151-171.

Psacharopoulos, G. (2000). Economics of Education a la Euro. European Journal of Education. Vol. 35 Issue 1, p. 81-95.

Psacharopoulos, G. \& Patrinos, H. A. (2002). Returns to Investment in Education: A Further Update. World Bank Policy Research Working Paper 2881. Washington.

Romer, P. (1990). Endogenous Technological Change. The Journal of Political Economy. Vol 98, No. 5, Part 2: The Problem of Developmnet: A Conference of the Institute for the Study of Free Enterprise Systems (Oct., 1990).

Romer, P. (1989). Increasing Returns and New Developements in The Theory of Growth. National Bureau of Economic Research. Working Papers Series, No. 3098. Massachusetts.

Romer, P. (1986). Increasing Returns and LongRun Growth. Journal of Political Economy 94, pp. 1002-1037.

Screpanti, E. \& Zamagni, S. (1993). An Outline of the History of Economic Thought. Claren- don Press. Oxford.

Solow, R. M. (1956). A Contribution to the Theory of Economic Growth. Quarterly Journal of Economics. Vol. 70, pp. 65-94.

Sudmant, W. (1999). The Economic Impact of the University of British Columbia on the Greater Vancouver Regional Destrict. Planning and Institutional Research. The University of British Columbia.

Vaherva, T \& Juva, S. (1985). Koulutuksen talous. Kustannusosakeyhtiö Tammi.

Woodhall, M. (1987a). Economics of Education: A Review. Teoksessa Psacharopoulos, G. (Ed.): Economics of Education. Research and Studies. Pergamon Press. A Wheaton \& Co. Ltd. UK. 